\title{
MULTILINGUISMO NA ESCOLA:CRENÇAS E ATITUDES LINGUÍSTICAS DE PROFESSORES DE LÍNGUA PARA/COM IMIGRANTES REFUGIADOS EM ESCOLAS PÚBLICAS DE CHAPECÓ
}

\author{
MULTILINGUISM IN SCHOOL: BELIEFS AND LANGUAGE ATTITUDES \\ OF LANGUAGE TEACHERS TO / WITH IMMIGRANTS REFUGEE IN \\ CHAPECÓ PUBLIC SCHOOLS
}

Cristiane Horst ${ }^{2}$

Julia do Nascimento Bertiotti ${ }^{3}$

\section{Resumo}

O ensino de língua portuguesa influencia no processo de integração social de estudantes em situação de refúgio e o professor tem grande importância nesse processo. Por isso, procura-se identificar e descrever crenças linguísticas de professores de línguas que lecionam em uma mesma sala de aula a alunos brasileiros e alunos imigrantes refugiados ou filhos de pessoas nessa situação. Procura-se investigar de que forma os professores se portam no acolhimento de diferentes culturas dentro dos espaços escolares, na promoção da tolerância e na inserção desses indivíduos nos contextos social e escolar. A partir da identificação das crenças, percebe-se como a formação dos professores e o suporte dado pelas instâncias organizacionais e políticas influenciam no que se refere a propiciar melhores condições para promover a manutenção e integração linguística e cultural e a sensibilização à diversidade no espaço escolar.

\section{Palavras-Chave}

Línguas minoritárias. Imigrantes refugiados. Professores de línguas. Crenças e atitudes linguísticas. Chapecó.

\begin{abstract}
The teaching of Portuguese language influences in the process of social integration of refugee students, and the teacher plays an important role in this process. This way, we intend to identify and describe linguistic beliefs of language teachers who teach in the same classroom to Brazilian students and refugee immigrants or refugees' kids. We seek to investigate how teachers behave in welcoming different cultures inside the school environment, and how they promote the tolerance when it comes to the insertion of these people in the school and social contexts. From the identification of the teachers' beliefs it has been realized how the teachers formation and the support given to them by organizational and political instances in influence concerning the providing of better conditions to promote the linguistic and cultural maintenance and integration, and the awareness of the diversity in the school environment.
\end{abstract}

\section{KeYwORDS}

Minority languages. Refugee immigrants. Language teachers. Linguistic beliefs and attitudes. Chapecó.

\footnotetext{
1 Este artigo é resultado de TCC apresentado ao Curso de Graduação em Letras - Português e Espanhol - Licenciatura Plena - da Universidade Federal da Fronteira Sul - UFFS, campus Chapecó.

2 Doutora em Letras - Filologia Românica pela Christian-Albrechts-Universität zu Kiel (Alemanha), Pesquisadora/Docente do Mestrado em Estudos Linguísticos - PPGEL e do Curso de Graduação em Letras Português e Espanhol da Universidade Federal da Fronteira Sul - Campus Chapecó - UFFS.

3 Graduada em Letras Português e Espanhol - Licenciatura pela Universidade Federal da Fronteira Sul, Campus Chapecó/SC
} 


\section{INTRODUÇÃo}

Quando imaginamos uma aula de ensino de línguas no Brasil, o pensamento é de que se trata, portanto, de uma aula para brasileiros que têm como língua materna a língua portuguesa. A ideia de que o Brasil é um país monolíngue está tão internalizada que, muitas vezes, esquecemos que, dentro de uma mesma sala de aula, é recorrente encontrarmos estudantes que têm, exercendo o papel da língua materna, outra(s) língua(s), e não somente o português.

O Brasil é um país formado por comunidades de (i)migrantes. Há séculos, populações chegam ao nosso país oriundas de todo o mundo, especialmente da Europa, Ásia e África, e mais recentemente da América, e trazem consigo suas culturas e línguas. A situação das línguas em contato, por conseguinte, das culturas em contato, é uma realidade antiga dos brasileiros. De acordo com Raso, Mello e Altenhofen (2011, p.13) “a história do Brasil após a chegada do homem branco é toda uma história de contatos linguísticos. Ao longo dos mais de cinco séculos depois do descobrimento, no território brasileiro conviveram, comunicaram e se misturaram populações ameríndias, européias, africanas e asiáticas".

Falando da região oeste de Santa Catarina, vemos muitas minorias linguísticas no espaço social e escolar. Segundo Horst, Krug e Fornara (2017, p.2), essa grande variedade linguística na região se deu pelo processo de colonização e ocupação que compõem a história dessa região, tanto pelas populações indígenas que aqui já habitavam, quanto com a vinda dos imigrantes europeus:

\footnotetext{
Até por volta do ano de 1900, ocupava a região, ao lado dos povos autóctones, Kaingang e Guarani, uma população de caboclos e mestiços, que vinham se refugiar na mata, fugidos de seus então "donos". A estes, ainda nas primeiras décadas do século XX, juntaram-se os povos alóctones, descendentes de imigrantes italianos, alemães, poloneses, russos e asiáticos, que passaram a fazer parte da paisagem linguística da região. Essas minorias étnicas utilizam, até hoje, em diversos contextos, uma ou mais variedades linguísticas distintas do português.
}

Apesar disso, é recorrente vermos e ouvirmos relatos de pessoas que suprimiram a língua falada em casa e/ou suas marcas na língua portuguesa no ambiente escolar. A pertinência deste debate cresce, quando analisamos o contexto histórico nacional de políticas linguísticas monolingualizadoras, especialmente durante a ditadura militar e a era Vargas, que se encarregaram de proibir e, até mesmo, criminalizar manifestações linguísticas em outros idiomas, que não o português, criando a falsa ideia de que o Brasil é, ou deveria ser, um país monolíngue. Até hoje, tais manifestações são reprimidas e desvalorizadas.

A ideia de que a língua portuguesa é a única língua falada em todo o país e, de que variantes que carregam marcas dessas outras línguas, especialmente no nível fonético e fonológico, é "errado", trouxe e, ainda traz, consequências para o ensino de línguas e a integração desses indivíduos na comunidade. Esse cenário se reforçou ainda mais dentro das escolas, onde só era permitido ensinar a língua portuguesa. Qualquer manifestação em outros idiomas, e/ou carregar a marca desses idiomas maternos no português era, e às vezes ainda é, considerado errado. Relly, Machado e Schneider (2008) ilustram, a título de exemplificação, o que se refere à proibição de uso de língua, que não fosse o português. (apud Horst, 2011, p. 65-66): 
A moradora D.B. em seu depoimento relata que a polícia rondava os salões de festa de Corvo, o que gerava insegurança em seus habitantes, uma vez que muitas pessoas não tinham sequer aprendido o Pt. e o fato de não poderem falar Al. dificultava as suas vidas. A moradora comenta também que alguns professores da época interromperam suas carreiras em função da proibição do $H d$. (Al.-P) nas salas de aula.

Eckert-Hoff (2010, p. 95) também nos relata como esse processo se deu nas escolas com a língua alemã:

\begin{abstract}
Naquele período, marcaram-me fortemente dois fatos na escola: o primeiro, diz respeito às faixas de campanhas que, afixadas na parede, ordenavam falar o português, isso na década de 70, quando cursei o ensino primário, numa escola rural pertencente ao município de São Carlos, Santa Catarina. Essas faixas, sempre em fundo branco, com letra de forma, em cor azul, traziam, no imperativo, diferentes dizeres: falem o português; proibido falar alemão na escola; seja um brasileiro, fale a lingua do País; aprenda a falar correto, falando somente o português. O segundo fato, decorrente do anterior, refere-se aos castigos dados pela escola para quem falava a língua alemã.
\end{abstract}

Nos últimos anos, temos presenciado, no Brasil, uma forte onda de imigração de pessoas em situação de refúgio, com destaque haitianos e senegaleses, desenhando um cenário linguístico e cultural ainda mais diversificado. O país fez parte da Convenção das Nações Unidas de 1951 e estabeleceu através do ACNUR (Alto Comissariado das Nações Unidas para os Refugiados) o Estatuto dos Refugiados e Apátridas. Tal estatuto garante aos estrangeiros refugiados, através da Lei 9474, o direito à carteira de trabalho, à inscrição no Cadastro de Pessoa Física (CPF), à saúde e à educação pública. A formação desse novo cenário linguístico minoritário, o das línguas de imigrantes refugiados, se mostra relevante para a pesquisa sobre como as aulas acontecem quando os estudantes trazem diferentes culturas e idiomas. Observando, portanto, o crescente número de estudantes de ensino regular que não têm o português como língua materna e pensando a necessidade de uma escola melhor preparada para integrar alunos de diferentes culturas e de ter o ensino de língua portuguesa como língua de acolhimento e integração, nos perguntamos de que forma a escola e o professor de línguas podem influenciar no processo de integração desses estudantes imigrantes refugiados na comunidade escolar.

É, ainda, necessário trazer à tona a discussão sobre xenofobia e racismo no contexto escolar. Ser um imigrante negro em situação de refúgio já é uma situação delicada por si só. Há dificuldades em reconstruir a vida em outro lugar por que já não é possível viver em seu país, em inserir-se em um mercado de trabalho que, na maior parte das vezes, não o valoriza simplesmente por ser um imigrante refugiado, e precisar romper a barreira linguística, torna tudo ainda mais complexo. Nesse sentido, o aprendizado da língua portuguesa e a experiência na escola são processos muito importantes que merecem uma atenção diferenciada no acolhimento dos refugiados no Brasil. Se esses aspectos forem tratados de forma adequada, o professor, em especial o professor de línguas, tem a possibilidade de promover a manutenção de questões de identidade e nacionalismo, ao mesmo tempo em que ensina a língua portuguesa, uma língua estrangeira para a maioria dos imigrantes.

Foi na busca de compreender se o espaço escolar é um ambiente em que essas manifestações são bem-vindas, bem vistas e valorizadas, além da reflexão acerca das concepções e crenças linguísticas de professores de língua da rede pública de Chapecó acerca do ensino em salas multilíngues e 
multiculturais, que esta pesquisa foi desenvolvida. Considerando que o multilinguismo é recorrente nas salas de aula da região oeste de Santa Catarina, tanto com descendentes de imigrantes do século XIX, quanto com os imigrantes mais recentes em situação de refúgio, nossa proposta de pesquisa teve como foco esse segundo grupo.

Nossa meta com o estudo é reconhecer/identificar ações de acolhimento linguístico por parte dos professores de línguas, a partir de aplicação de questionário de investigação sobre as crenças e atitudes linguísticas. Nossos objetivos com a pesquisa são: 1) compreender a realidade do ensino de línguas regular público para alunos refugiados; 2) identificar e reconhecer crenças dos professores de línguas acerca de aspectos relacionados ao ensino para alunos imigrantes refugiados estudantes do ensino regular público de Chapecó; 3) investigar fatores que influenciam no estabelecimento de tais crenças; 4) descrever práticas que afetam o processo de inclusão social e cultural dos estudantes em situação de refúgio; 5) sugerir práticas que auxiliam na inclusão social e cultural dos estudantes em situação de refúgio.

A identificação e compreensão das crenças de professores de língua relativas ao ensino para imigrantes refugiados no ensino regular na rede pública de Chapecó e, a presença desse tipo de discussão nas instituições de ensino, possibilita a ascensão social dos estudantes em situação de refúgio e suas famílias que estão se inserindo nos ambientes sociais, em especial na escola, através da valorização de suas culturas e línguas, pois de acordo com Grosso (2010), o ensino da língua portuguesa como língua de acolhimento "interliga-se a um diversificado saber que exige a partilha e a compreensão de aspectos culturais dos que chegam e daqueles que os acolhem, para além do conhecimento linguístico" (apud Soares, 2017, p. 197).

A formação dos professores e o suporte dado pelas instâncias organizacionais e políticas podem contribuir ou frear o processo de acolhimento dos estudantes em situação de refúgio nas aulas de língua e, por isso é importante compreender de que forma esse espaço tem promovido a manutenção e integração linguística e cultural e a sensibilização à diversidade e à tolerância na comunidade escolar. Levamos em conta as barreiras estruturais do nosso sistema de ensino público em aulas de língua multiculturais e multilíngues, a estruturação do currículo no tratamento dessas questões e nos orientamos a partir de conceitos relativos a bi e multilinguismo e bi e multicultura, línguas em contato, políticas linguísticas, racismo, xenofobia e representação social.

Pensando esse contexto, apresentaremos a seguir, o contexto histórico das línguas em contato, imigração, refúgio e os acordos e estatutos em se tratando de políticas linguísticas no Brasil, identificando como o refugiado se insere nesse cenário; os alinhavos teóricos e conceitos que embasaram nossa pesquisa a partir do viés sociolinguístico; a reflexão sobre as crenças e atitudes linguísticas de professores de línguas nas escolas da rede pública de Chapecó acerca do ensino para turmas multilíngues, além do processo de acolhimento de imigrantes em situação de refúgio.

\section{A imigração no Brasil e no oeste de Santa Catarina}

O Brasil é um país formado por imigrantes. A chegada dos portugueses ao nosso país, o tráfico de africanos feitos escravos, as políticas de povoamento das terras brasileiras que se encarregaram de trazer os imigrantes europeus e os povos indígenas que já estavam aqui, são apenas pinceladas do grande quadro que configurou a pluralidade do povo brasileiro (Raso, Mello e Altenhofen, 2011). Especificamente na região oeste de Santa Catarina, observamos um cenário 
bastante diverso. É uma região plural, tanto cultural, quanto linguisticamente, formada por povos indígenas Kaingang e Guarani, descendentes de imigrantes europeus (italianos, alemães, poloneses) e asiáticos (russos), além dos chamados caboclos e mestiços, como abordado por Horst, Krug e Fornara (2017).

Mais recentemente, observamos em nosso país um grande fluxo de imigrantes refugiados, em especial do Haiti, desde o terremoto de 2010. Durante sua participação na Convenção das Nações Unidas de 1951 através do ACNUR, o Brasil estabeleceu o Estatuto dos Refugiados e Apátridas, que define refugiado como a pessoa que

perseguida em virtude da sua raça, religião, nacionalidade, filiação em certo grupo social ou das suas opiniões políticas, se encontre fora do país de que tem a nacionalidade e não possa ou, em virtude daquele receio, não queira pedir a proteção daquele país; ou que, se não tiver nacionalidade e estiver fora do país no qual tinha a sua residência habitual após aqueles acontecimentos, não possa ou, em virtude do dito receio, a ele não queira voltar (ACNUR, 1951, p. 2).

O mesmo documento garante que todo imigrante refugiado goze, no país que lhe acolhe, de direitos humanos e das liberdades fundamentais, e nisso incluímos o acesso à educação. Se tratando desta, algumas questões se colocam em pauta.

\section{O ESTUdANTE IMIgRANTE REFugiado NA AULA de LínguA}

Estar em situação de refúgio envolve muitas barreiras e, quando se é um imigrante refugiado negro, ela pode se tornar ainda mais delicada, tanto no âmbito social, profissional, educacional ou de relações interpessoais. Os refugiados enfrentam problemas para se relacionar e conhecer outras pessoas e são vítimas de racismo e xenofobia diariamente. Em Lobo (2017, p. 61), temos acesso a alguns relatos, por exemplo:

Conheci outra estudante que também alega não conhecer racismo antes de vim ao Brasil. $\mathrm{Na}$ opinião de Joanie quando chegou no aeroporto em Porto Alegre ainda se sentia bem contudo, em Foz do Iguaçu sentiu o preconceito "nos olhares no ônibus". Para ela todos os lugares são locais de racismo, não se sentindo bem em nenhum lugar. Atualmente ela prefere ficar em casa e focar nos estudos, não vê outra alternativa senão voltar ao Haiti.

Ainda, segundo a mesma autora:

Os (não) espaços no caso das/os imigrantes, se formam justamente com a perda de direitos e vulnerabilidade causada pela dificuldade de se relacionarem devido ao preconceito/xenofobia/racismo/sexismo da sociedade que se encontram, por não dominarem a língua, por não estarem cientes dos poucos direitos que possuem e pelas condições de trabalho precários que lhe são impostas uma vez que na maioria das situações não lhe são concedidas/os melhores opções de emprego. Em geral, os imigrantes são os que realizam os trabalhos mais braçais, manuais e com risco de desenvolverem doenças geradas pelo trabalho (LOBO, 2017, p. 46).

É recorrente, ouvirmos relatos de imigrantes refugiados que têm dificuldade em inserir-se no mercado de trabalho, conforme Lobo (2017), pois as empresas, muitas vezes, não os valorizam, e essa realidade se assemelha à de Chapecó. Segundo Amado (2013): 
O perfil de muitos dos imigrantes refugiados retrata falantes bilíngues e até multilíngues. Aqueles que vêm de países do continente africano falam, via de regra, além do inglês ou do francês, línguas étnicas e/ou línguas crioulas. O mesmo ocorre com boa parte dos falantes do continente asiático, como os sírios e palestinos, que, além do árabe, falam inglês. Ou dos haitianos que, a par do francês, falam o crioulo haitiano. Muitos deles, inclusive, na rota de fuga, por viverem em outros países, acabam aprendendo outras línguas, antes de chegar ao Brasil, como os haitianos, que passam pelo Peru e Equador, e têm contato com o espanhol, por exemplo.

Apesar de muitos terem ensino superior e falarem mais de um idioma, é comum encontrarmos imigrantes refugiados negros trabalhando em funções mal pagas e não relacionadas à sua área de formação. Segundo Bulla et. al. (2017, p. 6)

Em geral, costuma-se perceber a presença da nacionalidade ocupando postos em empresas de serviços terceirizados, principalmente de limpeza, na construção civil, em indústrias frigoríficas e em serviços de limpeza urbana. Cargos que não exigem um alto nível de escolarização, apesar de muitos haitianos migrantes virem com diplomas de graduação do Haiti.

A superação da barreira linguística através da educação se torna parte fundamental no processo de acolhimento e integração dos refugiados nos espaços sociais. Inicialmente, porque o ensino, que leva em conta as diferentes culturas e línguas que compõem a realidade regional e nacional, promove o respeito, a tolerância e a manutenção linguística e cultural e dos estudantes. Esse respeito e tolerância, por sua vez, possibilitam que os alunos, e toda a comunidade escolar, se integrem mais, se relacionem melhor, entendam e respeitem o diferente e estejam envolvidos com o ambiente escolar de forma mais humana. Tudo isso possibilita a ascensão social e a melhora da qualidade de vida do estudante em situação de refúgio. Pereira (2017, p.128) cita Ançã (2008, p. 74) para falar sobre isso:

É com o estudo da língua portuguesa que o refugiado pode se manifestar e se assegurar efetivamente. O português, mais que uma nova língua, é um elemento de mediação do acolhimento e da construção da liberdade. De acordo com Ançã (2008), o domínio da língua é seguramente a via mais poderosa para a integração social, para a igualdade de oportunidades e para o exercício da plena cidadania: "O problema da língua de acolhimento coloca-se com toda a premência, sendo o domínio da LP uma das vias mais poderosas para a integração dos estrangeiros, tanto a nível individual (garantia da autonomia) como colectivo (harmonia social)".

Quando tratamos da aula de língua, esses pontos se tornam ainda mais marcantes. É importante que o professor tenha consciência de todos esses fatores para que o ensino se torne, de fato, um ensino que busca o acolhimento e a total integração dos estudantes.

\section{LínguAS EM CONTATO, POLÍTICAS LINGUísticas E A AULA DE LÍNGUA}

Compreendemos que as línguas em contato influenciam e enriquecem a experiência linguística dos indivíduos. No Brasil, diante da configuração plural de costumes e de línguas, idealiza-se uma aula de língua diversa, onde são bem-vindas, aceitas e valorizadas manifestações culturais e linguísticas de todos os alunos, independentemente da descendência, língua materna ou relação com a língua nacional. Apesar disso, sabemos que, muitas vezes, essa não é a realidade que se apresenta. 
O Brasil possui um histórico de políticas que buscavam seu estabelecimento como um país monolíngue e que, durante anos, se encarregaram de criar a falsa ideia de que somos um país que fala o mesmo e único idioma de norte a sul, privando e silenciando dialetos e línguas minoritárias. Segundo Calvet (2007, p. 11) “o poder político sempre privilegiou essa ou aquela língua, escolhendo governar o Estado numa língua ou mesmo impor à maioria a língua de uma minoria.” A política e planejamento linguístico, apesar de serem conceitos recentes, acontecem desde sempre, e normalmente têm a intenção de criar um sentimento de nacionalismo através da língua. No Brasil, apesar de pouco se falar sobre isso no ambiente escolar, temos um grande exemplo de planejamentos linguísticos (aplicações de políticas linguísticas) que tinham como intenção unificar a língua do povo brasileiro durante a ditadura militar e a era Vargas, como percebemos a seguir no decreto-lei $\mathrm{n}^{\circ} 1.545$ de agosto de 1939 :

Art. $1^{\circ}$ Todos os órgãos públicos federais, estaduais e municipais, e as entidades paraestatais são obrigados, na esfera de sua competência e nos termos desta lei, a concorrer para a perfeita adaptação, ao meio nacional, dos brasileiros descendentes de estrangeiros. Essa adaptação far-se-á pelo ensino e pelo uso da língua nacional, pelo cultivo da história do Brasil, pela incorporação em associações de caráter patriótico e por todos os meios que possam contribuir para a formação de uma consciência comum.

De acordo com Altenhofen (1996, p.17), tais políticas de nacionalização trouxeram diversas consequências, por exemplo, nas áreas onde predominava a língua alemã:

$1^{\circ}$ impediu o acesso ao ensino de alemão e o desenvolvimento de uma cultura letrada, em curso, nessa língua; $2^{\circ}$ exigiu o ensino exclusivo do português, sem dar condições necessárias para tal; $3^{\circ}$ obrigou a população alóctone a optar entre o silêncio e a variedade dialetal local que restou como língua de comunicação entre os membros do grupo.

Esse nacionalismo forçado através do idioma, desconsiderou a existência de pessoas que tinham outro idioma, que não a língua portuguesa como língua materna e, criminalizou essas manifestações linguísticas nos espaços sociais, escolares e até familiares. Aqui compreendemos língua materna como a língua da afetividade, da família. Segundo Altenhofen (2002, p. 151)

As condições de aquisição da língua materna, ou melhor, os traços que a caracterizam - primeira língua aprendida "naturalmente" na interação em um ambiente familiar" - conferem-lhe um valor afetivo especial para o desenvolvimento do indivíduo. (...) $\mathrm{Na}$ verdade, estabelece-se via de regra uma relação de identidade entre língua materna e família, tão forte como o vínculo que une mãe-pai e filho. Essa identidade afetiva é proporcional ao estilo de interação dos pais com as crianças e parece aumentar na medida em que a língua usada na família se distingue da língua do meio, como no caso dos falantes de línguas minoritárias.

As aulas de língua, a partir de então, passaram a ser aulas de língua portuguesa, "a única língua nacional", quando era proibido o uso de quaisquer outros idiomas na sala de aula, como podemos perceber, ainda no decreto-lei no 1.545 de agosto de 1939:

Parágrafo único. Aos professores e instrutores de qualquer espécie, bem como a todos os que se consagrem à tarefa de cuidar da infância e juventude, cumpre esforçarem-se por difundir o sentimento da nacionalidade e o amor da pátria. 
Art. 15. É proibido o uso de línguas estrangeiras nas repartições públicas, no recinto das casernas e durante o serviço militar.

Art. 16. Sem prejuízo do exercício público e livre do culto, as prédicas religiosas deverão ser feitas na língua nacional.

Art. 17. O Governo da União auxiliará os Estados para a organização de pequenas bibliotecas de livros nacionais nos centros de aglomeração de estrangeiros.

Esse histórico criou uma ideia que persiste ainda hoje de que a aula de língua portuguesa deveria ser uma aula de gramática normativa que ensina o "português correto" e apenas ele. Temos dificuldade em superar esses pensamentos nas instituições de ensino, e isso nos preocupa no que trata dos estudantes que têm outro idioma exercendo o papel de língua materna, não apenas tratando dos estudantes refugiados, mas de todas as minorias linguísticas.

No oeste de Santa Catarina, observamos e comprovamos através de diversos estudos, em destaque do projeto guarda-chuva Atlas das Línguas em Contato na Fronteira (KRUG, 2013), que muitas pessoas ainda falam outras línguas, dialetos ou variedades de outros idiomas no ambiente familiar. Segundo Funkler, Horst e Krug (2017), por exemplo, uma das principais variedades linguísticas da região é o Talian, que acabou sendo restringida apenas aos ambientes familiares em razão das campanhas de nacionalização no Brasil.

A escola precisa ser um lugar de acolhimento e interação entre-culturas e entre-línguas. Entretanto, em razão de todo o estigma que se criou, ainda vemos reflexos negativos. É comum que na escola não se fale sobre esse multilinguismo e que, ao mostrar marcas dessas línguas em variedades da língua portuguesa, os falantes sejam reprimidos e sua forma de falar considerada errada. Por essa razão é recorrente, no senso comum, ouvirmos falas que dizem "ele fala errado", "ela não sabe falar direito", "fale certo" ou "o correto é x e não y", tanto na esfera sintática, fonética, lexical ou semântica.

\section{Crenças, atitudes e comportamentos linguísticos: a escola e os PROFESSORES}

A partir dos fatores até então abordados no que se refere à tendência das aulas de língua não serem ambientes pluriculturais e plurilíngues por razões políticas e históricas, nos propusemos a verificar como esse ambiente se coloca atualmente na região no processo de acolhimento do aluno imigrante refugiado na região oeste de Santa Catarina, já que, de acordo com Grosso (2010), o aprendizado da língua portuguesa por esses indivíduos possibilita o domínio profissional, de direitos e de sua cidadania. As entrevistas a professores de línguas e a análise de suas crenças linguísticas são importantes nesse processo, pois de acordo com Busse e Sella (2012, p. 78),

O modo como os falantes concebem o outro em seu cotidiano pode ser percebido, por exemplo, por meio de fenômenos da variação linguística, contanto que se perceba, por meio da fala, como são externadas ações e "representações" sociais e culturais da comunidade. Ao tomarmos a língua como um conjunto estruturado, no qual estão representadas as relações sociais e a organização dos grupos, reconhecemos que ela é determinada pelas condições de existência do homem no tempo e no espaço, e que, quanto à sua composição, organização e uso, a fala é resultado da relação dinâmica entre os elementos internos e externos da língua. 
Buscando compreender um pouco sobre como se dá a aula de língua portuguesa nas escolas públicas regulares de Chapecó que têm em suas turmas estudantes que trazem diferentes línguas maternas, nossa proposta de pesquisa analisa as crenças e atitudes linguísticas dos professores. Mostra-se pertinente compreender essa teoria, pois segundo Molina (1987, p. 25), conforme citado por Aguilera (2008, p. 1) a atitude linguística

atua de forma muito ativa nas mudanças de código ou alternância de línguas; é um fator decisivo, junto à consciência linguística, na explicação da competência dos falantes; permite ao pesquisador aproximar-se do conhecimento das reações subjetivas diante da língua e/ou línguas que usam os falantes; e influi na aquisição de segundas línguas.

Bernieri (2017, p. 62) cita Lasagabaster (2004) quando diz que

Dentro do contexto social em que um indivíduo cresce, ele desenvolve atitudes em relação às pessoas e objetos de maneira geral. Estas atitudes podem ser positivas ou negativas, e podem levar o indivíduo a cultivar hábitos, como o de manter uma variedade minoritária ou não. As atitudes são "construções psicológicas", sentimentos que as pessoas nutrem acerca de um objeto, no caso da linguística, a investigação está na esfera destes sentimentos em relação à língua. Importante ressaltar que as atitudes são aprendidas, (LASAGABASTER 2004) assim, família e escola contribuem significativamente no fomento das atitudes de um indivíduo em relação a uma língua, e principalmente, ao grupo que utiliza determinada variedade, pois as atitudes frente a uma variedade refletem as atitudes frente a seus falantes, é uma correlação convencional (...)

O termo "atitude" é aqui compreendido como a forma (favorável ou desfavorável) sobre como os professores agem no que se refere a aspectos linguístico-culturais nas aulas de língua para estudantes estrangeiros em situação de refúgio. As atitudes linguísticas são estruturadas em três componentes, de acordo com Kaufmann (2011, p. 122): a componente cognitiva, a afetiva e a conativa. A cognitiva trata de convicções e crenças, a afetiva trata se a avaliação do objeto é positiva ou negativa e a conativa transforma as crenças e os valores emocionais em intenções comportamentais e refletem nas atitudes e intenções dos indivíduos. Já os comportamentos linguísticos estão relacionados à previsão que se faz de comportamentos a partir de suas crenças e atitudes.

O estudo das crenças e atitudes linguísticas de professores de línguas frente a situações de contatos linguísticos no ambiente escolar se mostra importante pois elas influenciam diretamente nas questões de valorização e manutenção de línguas minoritárias e no processo de integração social e linguística dos estudantes. A partir do conhecimento das crenças e atitudes linguísticas dos professores, buscamos compreender sua tendência de comportamento linguístico a fim de refletir o impacto desses aspectos na sala de aula de língua.

\section{OS INFORMANTES E A ATIVIDADE DE DOCÊNCIA}

Para a realização de nossa pesquisa, foram entrevistados dois professores de línguas do município de Chapecó. O primeiro de nossos informantes é do sexo masculino, possuía ensino superior completo em Letras - Português e Espanhol, graduado há um ano. O segundo, do sexo feminino, estudou magistério junto ao ensino médio, é graduado em Letras - Inglês há 4 anos, mestre em Estudos Linguísticos há 2 anos e atualmente cursa Letras - Português. 
No que trata da experiência dos informantes em sala de aula, o primeiro atua no magistério em aulas de Língua Portuguesa há 3 anos. O segundo atua no magistério há 8 anos, com ensino de inglês, português e com séries iniciais. Ambos os informantes participam todos os anos dos cursos de formação continuada. O segundo informante comenta, ainda, que acha que são oferecidos poucos cursos, e que eles deveriam dar ao professor a possibilidade de pensar a realidade da escola, cidade e região em que está, e que é papel do professor se manter em constante atualização, compreendendo que as gerações mudam e os alunos não são mais os mesmos, por isso, é preciso atualizar-se.

Os dois informantes se manifestaram de forma positiva com relação à atividade de docência, comentando que não gostariam de exercer outra profissão, gostam de seus trabalhos e se sentem bem atuando em sala de aula, mas também falam sobre a responsabilidade dessa profissão. O segundo informante opina ainda que a educação é a profissão que mais colabora com a formação de cidadãos, e que, por esse compromisso, "ser professor não é pra qualquer um”.

\section{O ESTUdo de línguas nO AMBiente escolar}

Perguntamos suas opiniões no que trata a importância do aprendizado de uma outra língua pelos alunos. Um deles pensa primeiramente nas línguas prestigiadas, como o inglês e o espanhol, dizendo que, caso no futuro tenha filhos, quer incentivá-los e matriculá-los em cursos de idiomas desde pequenos. Ao questionarmos sobre as línguas minoritárias / não prestigiadas / não elitizadas, ele traz um exemplo pessoal, relatando que em casa a mãe falava alemão, "alemão dialeto, não o alemão oficial", e ele e a irmã não foram ensinados. Acredita ser interessante as crianças aprenderem a língua falada em casa, pois quando adultos, eles cobrarão esse ensinamento dos pais, assim como ele e a irmã cobraram a mãe. Opina ainda que a escola deveria ter a liberdade de escolher qual idioma ensinar, além do inglês, adaptando à realidade da escola.

O segundo informante comenta que, como no início da carreira docente trabalhou com comunidades que falavam apenas o italiano e o alemão, algumas coisas o instigaram desde então no que trata da valorização da língua, do preconceito que os falantes de línguas minoritárias sofrem dentro e fora do ambiente escolar, do code-mixing, que é a mescla dos dois idiomas na fala ou na escrita, dizendo que "não pode ser errado, você não pode ser barrado de falar uma língua que é tão sua”, e por essa razão, ingressou no mestrado para pesquisar sobre diversidade linguística. Destaca também a importância de ensinarmos outras línguas na escola, enfatizando que não apenas o inglês é importante, e que em muitos países as pessoas falarem mais de uma língua é comum, mas no Brasil não temos essa cultura e essa valorização dos outros idiomas. Além disso, fala sobre as línguas minoritárias, dizendo que "a gente tem que defender essas línguas, porque não é só uma língua, ela faz parte de uma pessoa".

Ao perguntarmos suas opiniões no que trata as crianças que têm outro idioma dentro do ambiente familiar, ambos os professores destacam a importância do aprendizado desses idiomas por parte dos alunos e falam sobre suas experiências pessoais nesse cenário, acionando o componente afetivo: tinham contato, quando crianças, com um idioma dentro da escola e outro(s) em casa, mas não aprenderam aquele(s) falado(s) pelos pais e hoje se arrependem, pois sentem falta desses conhecimentos, seja pelo convívio familiar (no caso do primeiro informante), ou na vida profissional (para o segundo informante). Ainda sobre essa questão, o segundo informante comenta que no 
caso dos refugiados, acha que esse problema se intensifica, pois eles ainda têm uma relação muito forte com o país de origem:

(...) eu via pela forma que meus alunos comentavam que ligavam ou iam visitar a avó / tia, e que era sempre em crioulo ou francês. Às vezes na adolescência eles renegam a origem pelo sentimento de pertencimento. É importante que o professor trabalhe essas questões de pertencimento, de identidade, de valorização (...), pois em algum momento da vida eles vão sentir que perderam com isso.

Quando direcionamos essa pergunta para a especificidade das línguas não prestigiadas, o primeiro informante fala um pouco sobre a heterogeneidade das salas de aula em que trabalhava, que contavam com alunos imigrantes refugiados, como uma estudante haitiana que falava quatro idiomas, mas também com alunos de outras regiões do país que trazem outras variações da língua portuguesa, trazendo uma riqueza linguística muito grande para a aula.

\section{CODE-Mixing}

No que se refere ao code-mixing, a mistura dos códigos, o primeiro informante opina que a maior dificuldade dos contatos linguísticos na sala de aula é que sempre há influência / interferência de um idioma no outro, especialmente na atividade de escrita. Comentou ainda que alguns alunos trazem influência de outras línguas na escrita, relatando o caso de um estudante brasileiro que, segundo sua percepção, trazia características da língua inglesa. Sobre os alunos refugiados, relata que a única dificuldade era na habilidade escrita, que tinha bastantes interferências dos outros idiomas.

Já o segundo informante conta-nos que não percebeu nos alunos haitianos mistura de códigos. Acredita que os alunos se fiscalizavam para que isso não ocorresse e que tentava conscientizar os outros professores e a direção da escola, dizendo que "quando acontece é porque ele tem muito conhecimento em ambas as línguas". Também conta que não é favorável à ideia de obrigar os estudantes a escrever o português conforme a gramática tradicional, e que é preciso combater esse preconceito linguístico que é tão presente na história do nosso país.

\section{A discriminação}

No que tange à discriminação dos indivíduos em situação de refúgio, o segundo informante declara que "Chapecó é uma cidade muito preconceituosa, eles não aceitam, eles não querem se misturar com haitiano", relatando algumas de suas experiências, tanto dentro da escola, onde acredita que até mesmo os professores os discriminam, quanto em outros ambientes sociais, como a delegacia. Destaca que em muitos aspectos, a região não está preparada para receber os imigrantes:

porque quando a gente pensa assim: que os refugiados vieram pra cá, a maioria deles trabalha... mas não é só isso, sabe? jogaram as crianças nas escolas, não deram a preparação pra um professor, pra um gestor, nada... aí se a "criatura" cai na mão de um professor, de um gestor, que não tem noção nenhuma, aí tudo aquilo que a gente vem lutando pra valorizar as línguas minoritárias, pra valorizar essa língua que vem, pra não deixar que ocorra substituição (de línguas), isso vai ocorrer, por que não se tem preparação, não se tem conhecimento a respeito disso, sabe? então já tem a questão do preconceito...

\section{A escola no processo de integraçÃo}

Uma de nossas perguntas tratava da experiência dos professores com os alunos imigrantes. O primeiro informante relata que foi uma experiência "normal". Que não foi diferente de trabalhar 
com os outros alunos, que a aluna recebia as mesmas atividades e orientações. Opina ainda que na escola não há como fazer uma separação desses alunos, e por isso todos têm a mesma aula, independentemente do país ou cidade de onde vêm. Já o segundo informante, acredita que eles deveriam aprender a língua falada em casa, enfatizando os benefícios do aprendizado de outros idiomas. Ao pedirmos um relato das experiências linguísticas do professor, levando em conta os alunos que tinham uma língua no ambiente familiar e outra no ambiente escolar, relatou a participação da estudante haitiana no projeto de oratória da escola, contando que a interação dela com os colegas era "normal", dizendo posteriormente que os colegas costumavam rir dela durante o concurso. Relata ainda que ela quis participar do início ao fim:

(...) mesmo que o texto dela não ficou tão bom assim, (...) o texto dela a gente via que não tinha uma qualidade boa, assim... ficou curto, pequeno, por mais que eu tenha sugerido melhorias, ela levou o texto pra casa e trouxe ele menor ainda, não sei se não expliquei direito que era pra aumentar o texto... (risos). E ela foi até o final. O diretor da escola convidou ela, como ela não passou, para ser uma representante, fazer uma apresentação especial, representando os imigrantes, por que ela se desafiou, foi até o fim (...) Teve a parte dos professores que acharam justo, bacana, inclusão... teve outros acharam que não ficou legal, por que era uma semifinal e tal, uma situação que assim... enfim, tem sempre essa divisão.

Conta ainda uma situação que aconteceu com os alunos dos anos iniciais do ensino fundamental, que não falam a língua portuguesa:

Eu vi uma situação bem complicada, que assim, eles aprontavam na sala, e como que você vai xingar, chamar a atenção deles se eles não entendem o que você tá falando? E daí levaram lá pra secretaria, aquele monte de profe ao redor, tentando entender a versão deles do que tinha acontecido e a versão da profe.... chegava a ser engraçado. Os haitianos falando a língua deles, a secretária da escola tentando entender, tentando ver como que ela ia explicar pra eles, como resolver a situação, não tinha como. Criou toda uma situação lá na escola... 'vamos chamar alguém que entende pra conversar com eles', não acharam ninguém. E agora tem até o intérprete lá na escola para auxiliar, por que não tinha ninguém e daí ficou aquela situação: será que eles não tão falando português porque não querem, pra sacanear com a professora? Ficou uma situação bem complicada.

Já o segundo informante define a experiência como "muito realizadora", comentando que a oportunidade de trabalhar na prática com toda a teoria que havia estudado lhe foi muito positiva. Destaca a importância de valorizar a língua dos imigrantes, que os alunos refugiados agregam muito mais à aula do que ela pode ensiná-los, e que quando o professor consegue valorizar os aspectos linguísticos que eles trazem, eles se sentem muito orgulhosos. Contando um pouco sobre sua experiência, relata que teve contato com alunos que não falavam português e com alunos que já tinham aprendido, e que muitas vezes os professores entendem que se deve valorizar a cultura do aluno, mas não sabem como fazer isso na prática.

Teve um apoio muito grande da direção do colégio, que compreendia que ele, como especialista na área, poderia auxiliar no processo de integração desses alunos. Também entende que a escola costumava ser muito cuidadosa na questão da aprovação e reprovação desses estudantes, pois não queriam desmotivá-los por não falar português, mas incentivá-los a aprender. Essa escola tinha a intenção, junto com o professor, de construir um projeto com os alunos imigrantes refu- 
giados, como descreve o informante, com a intenção de "não apenas de ensinar o português, mas de fazer com que eles tenham uma convivência de ambas as línguas na vida deles". Infelizmente, o informante parou de trabalhar nessa escola e não sabe se o projeto continuou. Porém, conta um pouco sobre algumas das estratégias que utilizava.

Especifica o caso de uma aluna que vinha pra uma aula de apoio:

(...) ela não tinha dificuldade nenhuma (...) no início eu não conseguia identificar muito bem o quê que ela estava fazendo ali, ela escrevia muito bem e também ela comentava comigo dos outros alunos, do quanto eles estudavam, compravam muitos livros e enciclopédias nesses lugares mais acessíveis para conseguirem estudar. Você vê, assim, o esforço deles, e o quanto eles valorizam o professor, o professor na cultura deles é alguém que ainda é muito respeitado e muito valorizado, e essa aluna, eu constatei no final, que o que ela mais precisava era se aceitar 'eu falo sim e eu não tenho que ter vergonha por ter um pouco de sotaque no meu português' e foi isso que a gente trabalhou, e foi muito legal que a gente criou laços, ela me convidava pras apresentações de balé, me contava da família dela, que ela tinha tias em outros países por que a família meio que se dissipou no mundo, então ela ficou muito mais independente. (...) era muito mais um processo de fazer com que eles se compreendessem dentro do que acontece, se assumir, se aceitar.

Costumava incentivá-la, valorizando o fato de falar mais de uma língua, e cobrando-a para que não deixasse de estudar sua língua mãe, nem deixasse de falá-la em seu ambiente familiar.

Com uma aluna do $5^{\circ}$ ano que já falava muito bem o português, sempre pedia para que ela trouxesse para as aulas de inglês aspectos do francês, pensando em valorizar a língua dela. Costumava também questioná-la se ela continuava estudando o francês. Quando a aluna, disse que sim, que tem um professor de francês, mas às vezes ela não tinha muita vontade de estudar, incentivava: "é mais uma língua, é a tua língua, daqui a alguns dias você pode dar aula de francês, você pode ser a profe". Com essa mesma aluna, comenta:

(...) e eu pedia pra ela assim: 'como que eu falo 'com licença' em crioulo? Por que no ônibus a teacher não consegue nem pedir 'com licença”. (...) Aí um dia eu encontrei na rua um negócio que eu deduzi que era em crioulo, aí eu tirei uma foto e levei pra ela, pedi pra ela traduzir pra mim, por que eu acho que a valorização nesses casos, ela é essencial, valorizar ele e o que ele traz.

O informante relata que, posteriormente, nessa mesma turma, entrou um outro aluno haitiano, mas ele não sabia falar português. Essa aluna pôde auxiliá-lo e ele acabou se destacando em diversas disciplinas, mesmo com o pouco conhecimento do idioma.

Outro aspecto que lhe chamou a atenção foi a resistência dos profissionais da educação, destacando a necessidade de o professor estar aberto a novas teorias, conhecimentos, evolução dentro da própria área e mudanças sociais: "profe tem que ser estudante, ler teoria, ler artigo acadêmico (...)", mas também comenta que essa não é uma realidade tão simples: “a gente não pode culpar só o professor, porque eu tive a sorte de ter uma gestora que me consultava". Destaca também que procurava divulgar a existência do grupo de estudos Atlas das Línguas em Contato na Fronteira (ALCF), e os contatos dos professores da UFFS para auxílio.

Finaliza dizendo que a responsabilidade da escola nesse cenário é muito grande. Se essa consciência for divulgada na escola, em breve ela se expandirá para o resto da sociedade, e isso possibilitará uma melhora na vida dessas pessoas. Apesar de hoje existirem poucos alunos em situação 
de refúgio em nossas escolas, em alguns anos haverá mais, pois estão constituindo família e se estabilizando em nossa região, e em pouco tempo seus filhos também estarão nas escolas. Precisamos estar bem preparados para recebê-los.

\title{
Pedagogos de São Carlos e Coronel Freitas: uma análise adicional
}

Também utilizamos, para fins de análise, a pesquisa de Bernieri (2017), no que trata de crenças e atitudes linguísticas. Em sua dissertação intitulada "Crenças e atitudes linguísticas em relação a línguas minoritárias: alemão em São Carlos/SC e italiano em Coronel Freitas/SC” (2017), analisa as crenças linguísticas de

quatro pedagogas que atuam na educação infantil. Duas informantes são colegas e têm contato com crianças haitianas na rede pública de educação. As outras duas informantes, também colegas de trabalho, atuantes da rede privada de ensino, tiveram contato com crianças falantes de alemão (BERNIERI, 2017, p. 140).

Interessa acompanhar os resultados dos questionamentos feitos pela autora às suas informantes. A primeira pergunta trata da opinião dos professores sobre o aprendizado por parte das crianças da língua falada em casa, pelos pais. Todas se mostraram favoráveis, dizendo que é muito importante e destacando a facilidade que com que as crianças aprendem uma segunda língua, comparada ao adulto, além da forte relação que a língua têm com aspectos identitários e culturais.

A segunda pergunta pedia a opinião das professoras sobre o ensino de outras línguas, além do inglês, na escola. Segundo a autora,

\begin{abstract}
as respostas foram diversificadas: uma delas disse que pensa que deveria haver sim diversidade de ensino de línguas, especialmente por haver na região descendentes principalmente de alemães e italianos. Duas docentes, que têm contato com alunos haitianos, pensam que seria bom haver na escola o ensino de francês, para que as crianças brasileiras pudessem ter uma maior compreensão sobre a língua e cultura "do outro". E, referente a esta questão, uma das informantes manifestou que pensa não haver necessidade, de na educação infantil haver ensino de outros idiomas, além do inglês e do espanhol, pois "iria confundir muito as crianças" (BERNIERI, 2017, p.141).
\end{abstract}

A terceira pergunta traz à tona a questão do code-mixing, sobre o qual, segundo a autora, as informantes não demonstram grande preocupação, "declararam pensar ser esse um processo natural do desenvolvimento das habilidades da nova língua que está sendo aprendida: 'às vezes misturam, mas quando forem adquirindo mais maturidade, automaticamente vão diferenciando uma da outra"” (BERNIERI, 2017, p. 142).

A quarta questão trata da opinião das informantes acerca dos jovens que vivem no Brasil, possuem pais bilíngues, mas não aprenderam a língua falada em casa e hoje sabem e usam exclusivamente o português:

Duas das docentes pensam que isso ocorreu por falta de interesse destes jovens, somado a falta de incentivo dos pais, e as outras duas informantes docentes pensam que seria uma grande perda se estes alunos deixassem de falar o crioulo haitiano, pois isso restringiria suas relações com os membros de seu grupo étnico, principalmente com os que não moram no Brasil (BERNIERI, 2017, p.142). 
Por fim, a última pergunta pedia às informantes um relato de sua experiência com os contatos linguísticos na escola. Segundo a autora, "todas descreveram a experiência como algo estimulante". Relatam que as crianças sentiam-se curiosas e receptivas a diferentes culturas e línguas, e que, apesar da barreira linguística, tanto os alunos como os professores procuravam meios para tornar possível a comunicação:

Quando trabalhei com esta criança que falava alemão, vinham visitas na nossa sala, de outras turmas, porque as crianças queriam aprender, a língua que eles tinham contato na escola era uma outra língua, era diferente. Palavras que eles conheciam no português, no inglês, no alemão eles viam que era ainda uma outra forma de falar, então esta experiência foi muito feliz, muito rica em aprendizagem (BERNIERI, 2017, p. 142)

A autora ainda relata que:

Esta tranquilidade na comunicação entre as crianças durante aquisição de uma nova língua em contexto escolar, e especialmente o interesse voluntário dos colegas em observar, compreender e vivenciar esta diferença linguística, foi marcante no depoimento das informantes. Observamos este aspecto neste último depoimento que transcrevemos, em que houve a experiência, na escola, de uma criança que falava exclusivamente alemão ao iniciar sua vida escolar, e também no depoimento das docentes que têm experiências com crianças que falam o creoulo haitiano. Elas destacaram que esta curiosidade infantil não foi em relação à diferença física (a cor, por exemplo, diferente dos afro-descendentes com quem elas têm contato no Brasil), mas que as crianças ficavam intrigadas e curiosas com esta maneira diferente de falar, "queriam falar com ele, ver como era" (BERNIERI, 2017, p. 142).

\section{CONSIDERAÇões FINAIS: uM POSSÍVEL GESTO INTERPRETATIVO}

Diante do exposto, algumas questões se colocam em pauta no que trata as crenças linguísticas dos informantes na valorização do multilinguismo em sala de aula. É importante lembrar que os professores de línguas têm um papel muito importante nesse processo. Sendo o ambiente escolar um dos primeiros contatos sociais dos refugiados no Brasil, fazer da escola um local em que toda e qualquer manifestação linguística e cultural seja bem-vinda é fundamental. A análise dos dados coletados juntos aos professores reflete o estudo da realidade que se estabelece em sala de aula diante do contato do português com línguas de imigração, que formaram culturalmente a comunidade, e do português com línguas de falantes refugiados. Buscamos refletir nesse capítulo sobre a forma como as crenças dos professores no que trata os contatos linguísticos em sala de aula podem influenciar suas atitudes no ambiente escolar no processo de integração dos estudantes em situação de refúgio, além dos fatores que mais interferem nesse processo.

A região oeste de Santa Catarina, apesar de ser rica cultural e linguisticamente, em muitos aspectos não está preparada para receber e incluir o refugiado. Além dos conflitos e barreiras linguísticas e financeiras, o racismo e a xenofobia acabam por silenciar esses indivíduos. Esse não foi um aspecto identificado em nossas entrevistas, mas é recorrente na sociedade. Além disso, as crianças, de acordo com Bernieri, têm mais facilidade para lidar com essas diferenças físicas. As instituições de ensino muitas vezes vêem o estudante falante de uma língua minoritária como um problema, e não como uma possibilidade de agregar conhecimentos e experiências à aula. Muitas vezes, os alunos que trazem em sua fala ou escrita marcas do idioma materno ou de outra variante acabam 
sendo pressionados a perder essas características, mesmo que elas não dificultem o entendimento. A tentativa de padronização da língua por parte da escola e da sociedade é muito grande, como se fosse errado carregar essas marcas, essa identidade.

É importante que o professor destaque em sala de aula as vantagens de saber falar esses idiomas e valorize os estudantes que falam mais de uma língua, conscientizando os alunos de que não existe apenas um português correto, um alemão correto, um italiano, e assim por diante. A valorização das línguas minoritárias e dos estudantes que têm no ambiente familiar contato com mais de uma língua é indispensável nesse processo a fim de combater o preconceito linguístico, conforme orientam os parâmetros nacionais e estaduais para ensino de línguas, como a Base Nacional Comum Curricular e a Proposta Curricular de Santa Catarina, elaboradas por estudiosos da categoria da educação. Portanto, a escola deve ensinar a norma padrão da língua, mas também é seu papel conscientizar os estudantes para o respeito e a valorização da diversidade cultural e linguística. $\mathrm{O}$ aprendizado da língua portuguesa deve andar junto com a construção da ascensão social, apoio emocional e valorização cultural, visando a manutenção linguística e de nacionalismo. E mesmo assim, deve ser compreendido como um processo que leva tempo, exige compreensão, dedicação e prática, e que varia muito de acordo com a idade, perfil e acesso do estudante. Acima de tudo, é importante que as instituições de ensino e os professores percebam o estudante imigrante refugiado como um aluno que tem, mais do que necessidades linguísticas, necessidades de socialização e inclusão.

Percebemos a importância dos estudos nas áreas de variação linguística, bilinguismo e ensino de línguas por parte dos professores quando analisamos, a partir das crenças e atitudes linguísticas, considerando sua formação, áreas de atuação, se continuam estudando e se aperfeiçoando. Todos os informantes possuem uma boa relação com a atividade de docência, um alto nível de qualificação, são jovens, participam dos cursos de formação e se graduaram há pouco tempo ou ainda estão estudando. No que trata a oferta de cursos, é importante levarmos em consideração o fato de que as universidades frequentemente oferecem cursos, debates e palestras na área, além dos cursos de formação continuada dos professores, mas grande parte desses não conseguem participar e ter acesso a esses eventos pela sobrecarga de trabalho, falta de tempo para estudo, preparação e correção. É recorrente conhecermos professores insatisfeitos, desvalorizados e desmotivados. Isso acaba por refletir direta e primeiramente na sala de aula. Sabemos que é essencial que o professor goste do que faz e que perceba que as mudanças na sociedade devem ser promovidas de forma gradativa, por todos, especialmente pelos profissional da educação. Porém, sabemos que muitas vezes essa não é a realidade de todos os professores. A direção da escola possui um papel muito significativo nesse processo. É importante que esta esteja consciente dos fatores que envolvem o acolhimento de um estudante imigrante refugiado, e prepare toda a comunidade escolar para isso, seja ao estar atento às necessidades linguísticas e de acesso do estudante e de sua família, ao promover oportunidades para que ele seja ouvido, ao adaptar os ambientes e atividades para que possam participar e se sentir incluídos, entre outros.

Percebemos que, apesar de os professores acreditarem que as escolas devem promover um ambiente cultural e linguisticamente plural, muitas vezes, têm dificuldade em fazê-lo em sala de aula. De acordo com o artigo 13 da Constituição Brasileira de 1988: "A Língua Portuguesa é o idioma 
oficial da República Federativa do Brasil". Vemos, portanto que as instâncias organizacionais e políticas muitas vezes não consideram a sala de aula multilíngue. Aquelas pelas quais os professores realizam os cursos de formação preparam o professor de maneira insuficiente para essa realidade: os cursos de formação não tratam do falante de línguas minoritárias e é comum que se segregue esses estudantes, ignorando a situação. Por isso, percebemos a importância de uma formação continuada para os docentes voltada para a realidade de sua escola e região. Além disso, trazer para as instituições de ensino superior essa discussão abre caminho para uma formação mais humana e professores melhor preparados para lidar com as línguas em contato na escola, além de manter uma relação entre o ensino superior e o ensino básico, abrindo espaço para que os professores pensem e questionem essas problemáticas.

Em dois extremos, as visões de que o aluno imigrante é incapaz ou que é um aluno como outro qualquer acabam por prejudicá-los. A escola precisa ver o aluno imigrante como um aluno com necessidades linguísticas e sociais diferentes das do aluno brasileiro, como um estudante que possui uma história, que precisa ser ouvido. É papel da escola combater o silenciamento e esquecimento das vidas e línguas desses indivíduos. É também papel da escola manter as variedades que chegam à sala de aula, valorizá-las e explorar todos os aspectos que vêm por trás da língua. É importante que o professor e a escola valorizem a história, os conhecimentos e as diferentes culturas a fim de que se sintam abertos para falar e ser ouvidos, e isso pode ser feito com pequenas atitudes: desde ouvir suas histórias, as razões do refúgio, sua língua, seus problemas e dificuldades de adaptação ao novo país, até incentivá-los a não esquecer sua língua mãe, promover oportunidades para que se expressem, conscientizar o membros da comunidade escolar da importância de estarmos atentos às suas necessidades e combater o racismo e a xenofobia. É papel do professor e da escola promover a tolerância e a manutenção linguística e formar cidadãos preparados e conscientes de seu papel na sociedade. É também seu papel dar espaço e valorizar toda e qualquer manifestação cultural e linguística.

Também ressaltamos a importância de trazer para as instituições de ensino a discussão sobre as salas de aula multilíngues e multiculturais de ensino regular, o debate acerca das políticas linguísticas que barram ou incentivam o cenário multilíngue nas aulas de língua na escola, além do incentivo a pesquisas sobre a realidade linguística, na busca pela compreensão do panorama de línguas em contato da nossa região na contemporaneidade e trazer os principais aspectos no que trata do processo de acolhimento do estudante imigrante refugiado. Compreender as crenças dos professores de língua da região de Chapecó é um pequeno passo para a compreensão do panorama das línguas em contato na escola. A situação das línguas minoritárias e dos estudantes imigrantes refugiados, apesar de ser recorrente, não é muito trabalhada na sala de aula, e a busca pelo respeito à diversidade e promoção da tolerância devem ser constantes.

A partir de nossa pesquisa, percebemos que os professores possuem uma boa relação com todos esses fatores, mas a preparação e a formação ainda são grandes desafios. É necessário uma constante busca por informações, materiais e métodos que visam a inclusão dessa pluralidade na aula de língua e na escola como um todo, mas é necessário que o professor tenha melhores condições para fazê-lo. A maior problemática continua sendo a valorização e condições de trabalho dos professores a fim de buscar possibilidades cada vez melhores conjunturas para fazer da escola um 
ambiente rico em línguas, raças e culturas. Pontuamos, portanto, a necessidade da atenção de toda a comunidade escolar e dos profissionais da área de educação no que trata a promoção e valorização das questões de identidade, cultura e valorização nas salas de aula multilíngues e multiculturais.

\section{REFERÊNCIAS}

AGUILERA, V. A. Crenças e atitudes linguísticas: o que dizem os falantes das capitais brasileiras. São Paulo. Estudos Linguísticos, v. 37 (2), 2008.

ALTENHOFEN, C. V. O Conceito de Língua Materna e suas implicações para o estudo do Bilingüismo (Alemão-Português). Martius-Staden Jahrbuch, v. 49, 2002, p. 141-161.

ALTENHOEN, C. V.; MELLO, H.; RASO, T. Os contatos linguísticos no Brasil: dinâmicas pré-históricas, históricas e sociopolíticas. In: ALTENHOEN, C. V.; MELLO, H.; RASO, T. Os contatos linguísticos no Brasil. Belo Horizonte: UFMG, 2011, p. 13-56.

ALTO COMISSARIADO DAS NAÇÕES UNIDAS PARA OS REFUGIADOS (ACNUR). Convenção relativa ao Estatuto dos Refugiados. Nova Iorque, EUA: ACNUR, 1951. Disponível em: http://bit. ly/2uiYnGn. Acesso em: 07 jun. 2018.

AMADO, R. S. O português como língua de acolhimento para refugiados. Revista da SIPLE. Brasilia, Ano 4, n. 2, Out. 2013. [online]. Disponível em: http://bit.ly/38m7kxq. Acesso em: 16 mai. 2018.

BERNIERI, S. R. Crenças e atitudes linguísticas em relação a línguas minoritárias: alemão em São Carlos/ SC e italiano em Coronel Freitas/SC. Chapecó: UFFS, 2017.

BUSSE, S.; SELLA, A. F. Uma análise das crenças e atitudes linguísticas dos falantes do oeste do Paraná. Signum: Estud. Ling., Londrina, n. 15/1, 2012, p. 77-93.

BRASIL. Constituição, 1988. Constituição: República Federativa do Brasil. Brasília: Senado Federal, 1988.

BRASIL. Decreto-lei n. 1.545, de 25 de agosto de 1939. Disponível em: http://bit.ly/30xyhM4. Acesso em: 8 jun. 2018

BULLA, G. S.; SILVA, R. L.; LUCENA, J. C.; SILVA, L. P. Imigração, Refúgio e Políticas Línguísticas no Brasil: Reflexões Sobre Escola Plurilíngue e Formação de Professores a Partir de Uma Prática Educacional com Haitianos. Organon, v. 32, n. 62, 2017.

CALVET, J. L. As políticas Linguísticas. São Paulo, 2007.

CAVALCANTI, M. C. Estudos sobre educação bilíngüe e escolarização em contextos de minorias lingüísticas no Brasil. Delta, v. 15, n. especial, 1999.

ECKERT-HOFF, B. (Dis)sabores da língua ma(e)terna: os conflitos de um entre-lugar. IN: ECKERTHOFF, B. e CORACINI, MJRF. Escrit(ur)a de si e alteridade no espaço papel-tela. Campinas: Mercado de Letras, 2010, p. 79-106.

FUNKLER, D. I.; HORST, C.; KRUG, M. J. Crenças e atitudes linguísticas de falantes ítalo-brasileiros em Chapecó-SC. Sociodialeto. v. 7, 2017, p. 211-248.

GROSSO, M. Língua de acolhimento, língua de integração. Horizontes de Línguística Aplicada. v. 9, n.2, 2010, p. 61-77.

HORST, C. A situação da alfabetização dos falantes de línguas de imigração no contexto brasileiro. Revista Contingentia, 2009.

HORST, C. "Quando o Heinrich casa com a Iracema, a Urmutter vira bisa": A dinâmica dos nomes próprios de pessoas e comuns de parentesco em uma comunidade de contato alemão-português do sul do Brasil Kiel: Westensee-Verl, 2011.

HORST, C.; FORNARA, A. E.; KRUG, M. Estratégias de Manutenção e Revitalização Linguística no Oeste Catarinense. Organon, v. 32, n. 62, 2017.

KAUFMANN, G. Atitudes na sociolinguística: aspectos teóricos e metodológicos. In: RASO, T.; MELLO, H.; ALTENHOFEN, C. V. (Orgs.). Os contatos linguísticos do Brasil. Belo Horizonte: UFMG, 2011. p. $187-216$. 
KING, K.; MACKEY, A. The bilingual edge: Why, when and how to teach your child a second language. New York: Harper Collins Publisher, 2007.

LOBO, J. A. Racismo e patriarcado como sistema internacional: uma análise antropológica das relações Brasil-Haiti. 2017. 107 páginas. Trabalho de conclusão de curso (Graduação em Antropologia e Diversidade Cultural Latinoamericana). Universidade Federal da Integração Latino-Americana, Foz do Iguaçu, 2017.

PAYER, M.O. Processos de identificação sujeito/língua: ensino, língua nacional e língua materna. IN: ORLANDI, E. Política linguística no Brasil. Campinas: Pontes, 2007, p.113-123.

PEREIRA, G. F. O português como língua de acolhimento e interação: a busca pela autonomia por pessoas em situação de refúgio no Brasil. Cadernos de Pós-Graduação em Letras v. 17, n. 1, São Paulo: 2017, p. $118-134$.

MELLO, Heliana; ALTENHOFEN, Cléo Vilson; RASO, Tommaso (Orgs.). Os contatos linguísticos no Brasil. Belo Horizonte: UFMG, 2011.

SOARES, L. F.; TIRLONI, L. P. Rakonte Mwen: um projeto de ensino de português brasileiro a imigrantes haitianos a partir da literatura popular. Revista X v. 12, n. 2, Curitiba: 2017, p. 192-216.

Recebido em 30/9/2019 Aceito em 23/11/2019 